Research Paper

\title{
The Composition of Root Exudates from Two Different Resistant Peanut Cultivars and Their Effects on the Growth of Soil-Borne Pathogen
}

\author{
Xiao-gang $\mathrm{Li}^{1}{ }^{\bowtie}$, Tao-lin Zhang ${ }^{1}$, Xing-xiang Wang ${ }^{1,3}{ }^{凶}$, Ke Hua $^{2}$, Ling Zhao ${ }^{1}$, Zheng-min Han² \\ 1. Key Laboratory of Soil Environment and Pollution Remediation, Institute of Soil Science, Chinese Academy of Sciences, Nanjing 210008, \\ China; \\ 2. College of Forest Resources and Environment, Nanjing Forestry University, Nanjing 210037, China; \\ 3. Jiangxi Key Laboratory of Ecological Research of Red Soil, Ecological Experimental Station of Red Soil, Chinese Academy of Sciences, \\ Yingtan 335211, China.
}

\begin{abstract}
$\square$ Corresponding author: Prof. Xing-xiang Wang, Institute of Soil Science, Chinese Academy of Sciences, Nanjing 210008, China. E-mail: xxwang@issas.ac.cn Tel: +86-25-86881200 Fax: +86-25-86881000 or Dr. Xiao-gang Li, E-mail: xgli@issas.ac.cn.

(c) Ivyspring International Publisher. This is an open-access article distributed under the terms of the Creative Commons License (http://creativecommons.org/ licenses/by-nc-nd/3.0/). Reproduction is permitted for personal, noncommercial use, provided that the article is in whole, unmodified, and properly cited.
\end{abstract}

Received: 2012.11.22; Accepted: 2013.01.21; Published: 2013.02.01

\begin{abstract}
The high incidence of various soil-borne diseases in the monoculture field of peanut is a major production constraint in the red soil regions of southern China. The peanut root exudates are generally thought to play an important role in regulating soil-borne pathogens. The responses of the soil-borne pathogens, Fusarium oxysporum and $F$. solani to the peanut root exudates were studied using one susceptible cultivar Ganhua-5 (GH) and one mid-resistant cultivar Quanhua-7 $(\mathrm{QH})$ as the test materials. The components and contents of the amino acids, sugars and phenolic acids in the peanut root exudates were determined. The results demonstrated that the root exudates from both susceptible and mid-resistant cultivars significantly promoted the spore germination, sporulation and mycelial growth of soil-borne pathogens, F. oxysporum, F. solani compared with the control. The extent of the stimulation was depended on the strains of the Fusarium tested, and gradually increased with the increased concentrations of peanut root exudates. HPLC analysis showed that the contents of sugars, alanine, total amino acids in the root exudates of $\mathrm{GH}$ were significantly higher than that in $\mathrm{QH}$, whereas the contents of p-hydroxybenzoic acid, benzoic acid, p-coumaric acid and total phenolic acids were significantly lower than that in $\mathrm{QH}$. Results of the study suggested that the differences in the root exudates from the different peanut cultivars were considered to regulate the wilt-resistance mechanism in the rhizosphere of peanut. The results are therefore crucial important to illustrate the mechanism of peanut replanted obstacle, and to develop its control techniques in the red soil regions of southern China.
\end{abstract}

Key words: Peanut, Root exudates, Soil-borne pathogens, Amino acids, Phenolic acids.

\section{Introduction}

Peanut (Arachis hypogaea L.) is an important oil and cash crop all over the world. China is a major peanut producing country covering an area of more than $4700 \mathrm{khm}^{2}$ in 2011 growing season. Due to the limited arable land and requirement for intensifying regional agro-industrialization, peanut was generally monocropped on a large scale, and even monocropped over 20 years in some fields in the hilly red soil regions of southern China [1, 2]. Peanut diseases caused by soil pathogenic fungi are a limiting factor in 
peanut production, and have gradually increased with prolonged planting-year of peanut in recent decades $[1,3]$. In China, brown root rot disease caused by F. oxysporum, F. solani and so on resulting in the death of adult plants and fruit decay in peanut is a major disease that limits the growth and productivity of peanut and causes significant economic losses. According to Wang and Chen (2005), the increasing damage by soil-borne fungi, reaching disease incidence of $60 \%$ in some fields, was the main reason for the yield loss of peanut [1].

Root exudation includes the secretion of a diverse array of carbon-containing primary metabolites, such as sugars, amino acids in addition to more complex secondary compounds, involves the nutrient and water acquisition, plant defence and stimulatory or inhibitory interactions with other soil organisms [4]. The quantity and quality of root exudates depends on plant species, cultivar, growth stage and environmental factors. Root exudates from some plant species can inhibit potential soil-borne pathogens by releasing allelochemicals, while other promote the growth of pathogens [5-7]. The composition of root exudates from the wilt-susceptible and wilt-resistant plants was different, and had the different impact on the spore germination of F. oxysporum [8]. Yuan et al. (2002) and $\mathrm{Wu}$ et al. (2007) found that the contents and kinds of sugars, amino acids in the root exudates of disease-susceptible cotton varieties were more abundant than that in disease-resistant cotton $[9,10]$. Fungal pathogens also depend on these exogenous carbon sources for the growth as they are heterotrophic organisms [11]. However, little information is available whether the root exudates of peanut have the pathogenic impact on Fusarium.

In continuous monocropping systems, plant root exudates provide pathogens with a substrate supply over time and space, sometimes leading to significant colonization and infection by pathogens. Recently, a number of research findings of the negative relationship between the sugar and amino acid content in root exudates and the resistance of plants to Fusarium wilt or Verticillium wilt have been documented [12-14]. We tested the hypothesis that root exudates as a media substrate in the process of peanut-soil pathogens interactions, stimulate the growth of soil-borne fungi. Therefore, this study was performed to determine the types and amounts of compounds present in the peanut root exudates, and to investigate their effects on the growth of soil-borne fungi in vitro. This provides a new insight to understand the ecological interactions of peanut root exudates-soil-borne pathogens, and explain the increased incidence of root rot in peanut monocropping field.

\section{Materials and methods}

\section{Peanuts and pathogen strains}

Guanhua-5 (GH) was cultivated by the reclamation farm of Liu-Jia station, Yingtan, Jiangxi Province, China, and was bred from parental peanut Yueyou551-11 by the radiation. It has the good resistance to leaf spot and rust disease but susceptible to disease caused by soil-borne pathogens, and was the main planting variety in the red soil regions of Jiangxi Province [15]. Quanhua-7 (QH) was cultivated by the Quanzhou Institute of Agricultural Sciences, and was bred through the sexual hybridization between "028-9" (female parent) and "205-1" (male parent). It has the good resistance to diseases caused by soil-borne pathogens, and was the main planting variety in the hilly regions of Fujian Province, China [16].

In our study, a strain of $F$. oxysporum $\mathrm{f}$. sp.vasinfectum (Atk.) Snyder et Hansen provided by the Cotton Research Institute, Chinese Academy of Agricultural Sciences (CAAS) was used for fungal experiments. This fungus is a race-7 strain that causes cotton Fusarium wilt and is widely distributed throughout the Yangtze River Basin and the Yellow River Basin of China. A strain of peanut root rot, F. solani was also used in this study that was isolated from the infected peanut plants by the Institute of Plant Protection, CAAS, and was provided by the Institute of Agricultural Resources and Regional Planning, CAAS.

\section{Collection and treatment of peanut root exu- dates}

Peanut seeds were surface-disinfected in $0.5 \%$ sodium hypochlorite $(\mathrm{NaOCl})$ for $5 \mathrm{~min}$, followed by three times washes in sterile distilled water. Seeds were then transferred to PDA medium in $90-\mathrm{mm}$ diameter Petri dishes and held in a biochemical incubator at room temperature for $4 \mathrm{~d}$ until they pre-germinated. Contaminated seeds that had internal fungal infection were discarded and not used in the study. Seedlings of similar size $(\sim 3 \mathrm{~cm}$ height) were selected and cultivated in the culture dishes containing sterile vermiculite under growth chamber conditions at a day/night cycle: $16 \mathrm{~h}, 30 \pm 2{ }^{\circ} \mathrm{C} / 8 \mathrm{~h}$, $25 \pm 2{ }^{\circ} \mathrm{C}$ and $75 \%$ relative humidity. The Hoagland's nutrient solution was added every two days.

After thirty days of cultivation, the whole root systems of intact plants were carefully washed with running de-ionized water to remove the vermiculite. To collect the root exudates, all plantlets were placed into sterile $500-\mathrm{mL}$ glass container covered with aluminum foil paper to avoid contamination and light, 
and the roots were completely submerged in $300 \mathrm{~mL}$ of sterile aerated de-ionized water. Each peanut variety was cultured in triplicate and each repetition contained 4 peanut seedlings. Plantlets were maintained in a biochemical incubator at $30{ }^{\circ} \mathrm{C}$ for $24 \mathrm{~h}$ to collect root exudates. The collected root exudates were filtered by a double layer of Whatman no. 1 filter paper, and immediately frozen at $-30^{\circ} \mathrm{C}$, freeze-dried, and weighed. The lyophilized powder of root exudates was dissolved in deionized water to make concentrated extracts $1 \mathrm{~g} / \mathrm{L}$ for the bioassay and the analysis of the composition of organic components.

\section{The effect of peanut root exudates on the spore germination of soil-borne pathogens in vitro}

A stock culture of F. oxysporum and F. solani was maintained on slants of PDA at $4{ }^{\circ} \mathrm{C}$. For the preparation of the conidial suspensions, a block of the stock culture was transferred to PDA medium for $4 \mathrm{~d}$ at 28 ${ }^{\circ} \mathrm{C}$ in the dark and was subcultured once a week. The mycelium from 5 Petri dishes was scraped, mixed in $10 \mathrm{~mL}$ sterile deionized water and rubbing the surface with a sterile L-shaped spreader. The spore suspension was transferred to the sterile centrifuge tube, then concentrated $(3000 \times \mathrm{g}, 10 \mathrm{~min})$ and adjusted to a final concentration of $1 \times 10^{3}$ conidia/mL in sterile deionized water using a haemocytometer. The effects of root exudates on spore germination were determined by adding different concentrations of peanut root exudates to concave glass slides (3-wells, CAT. NO.7101, China). The collected exudates from GH and $\mathrm{QH}$ seedlings were diluted to 3 concentrations, $0.1 \mathrm{~g} / \mathrm{L}, 0.5 \mathrm{~g} / \mathrm{L}, 1 \mathrm{~g} / \mathrm{L}$ respectively, then filtered through $0.22 \mu \mathrm{m}$ sterile filters (Peninsula, Millipore, Shanghai, China). $50 \mu \mathrm{L}$ of the root exudates were mixed with $50 \mu \mathrm{L}$ of spore suspension and incubated at $25^{\circ} \mathrm{C}$ in the dark. For the control treatment, $50 \mu \mathrm{L}$ of sterile deionized water was added instead of root exudates to $50 \mu \mathrm{L}$ spore suspension. All experiments were performed in triplicate and independently replicated three times. After $5 \mathrm{~h}$, the spore germination was determined microscopically by counting 10 fields $(40 \times$ objective)/well. A spore was considered germinated if the germ tube length was at least as long as the length of the spore.

\section{The effect of root exudates on the mycelial growth of soil-borne pathogens in vitro}

Individual plates of water agar (WA) were excised in the center of the plate by cutting out a square of $1.5 \mathrm{~cm} \times 1.5 \mathrm{~cm}$ to form a well in which a plug of a 7-day olds colony of pathogen grown in PDA was placed. An aliquot $(200 \mu \mathrm{L})$ of the total exudates of
$\mathrm{GH}$ and $\mathrm{QH}$ at the concentrations of $0.1 \mathrm{~g} / \mathrm{L}, 0.5 \mathrm{~g} / \mathrm{L}$, $1 \mathrm{~g} / \mathrm{L}$, were then poured into the well containing the fungi plug. The addition of $200 \mu \mathrm{L}$ sterile deionized water to the well of WA was used as the control. Exudates retrieval was conducted as previously described. After total exudates addition, plates were incubated at $25 \pm 1{ }^{\circ} \mathrm{C}$ in the dark for $48 \mathrm{~h}$. Radial growth of F. oxysporum and F. solani was estimated by calculating the distance $(\mathrm{cm})$ from four equidistant points from the center of the plug to the end of colony growth. The experiments were performed in triplicate and independently replicated three times.

\section{The effect of peanut root exudates on the sporulation of soil-borne pathogens in vitro}

To determinate the sporulation capacity of the pathogens, Bilay's medium was used [17]. $1 \mathrm{~mL}$ root exudates of $\mathrm{GH}$ and $\mathrm{QH}$ with various concentrations of $0.1 \mathrm{~g} / \mathrm{L}, 0.5 \mathrm{~g} / \mathrm{L}, 1 \mathrm{~g} / \mathrm{L}$ and $1 \mathrm{~mL}$ sterile deionized water were added into the liquid medium to give a total volume of $10 \mathrm{~mL}$ per $50 \mathrm{~mL}$ Erlenmeyer flask respectively. Aliquots of $100 \mu \mathrm{L}$ spore suspension of $2 \times 10^{5}$ spores/ $\mathrm{mL}$ were inoculated into the liquid medium, and then incubated in a liquid shaker with 120 $\mathrm{rev} / \mathrm{min}$ at $28^{\circ} \mathrm{C}$. During the incubation time $48 \mathrm{~h}, 100$ $\mu \mathrm{L}$ of culture broth diluted to $10^{-4}$ was spread onto PDA. Plates were incubated at $28^{\circ} \mathrm{C}$ in the dark for 2 $\mathrm{d}$, after which colonies were counted and converted to the number of conidia in a liquid culture.

\section{Determination of soluble sugar, amino acids and phenolic acids in peanut root exudates}

Exudates collected from the peanut roots were filtered through a $0.22 \mu \mathrm{m}$ filter prior to the determination of the contents of soluble sugar, amino acids and phenolic acids. The components and contents of the amino acids were determined using high performance liquid chromatography (HPLC) for amino acids (HP1100, USA) as previously described by Li et al. (2009) [14]. In brief, chromatographic column: $4.0 \times 125 \mathrm{~mm} \mathrm{C}_{18}$, temperature of column: $40{ }^{\circ} \mathrm{C}$, velocity of flow: $1.0 \mathrm{~mL} / \mathrm{min}$, wavelength: $338 \mathrm{~nm}, 262 \mathrm{~nm}$ (Pro), mobile phase: A: $20 \mathrm{mmol}$ sodium acetate solution, B: 20 mmol sodium acetate solution : methanol : acetonitrile $=1: 2: 2(\mathrm{v} / \mathrm{v} / \mathrm{v})$. The content of soluble sugar was assayed by anthrone colorimetry.

Seven kinds of common phenolic acids were isolated and identified from peanut root exudates using high-performance liquid chromatography (HPLC) (Agilent 1200, Germany) referring to the method of Hao et al. (2010) [7]. The analytical conditions were as follows: chromatographic column: $\mathrm{XDB}-\mathrm{C}_{18}(4.6 \mathrm{~mm} \times 250 \mathrm{~mm})$, temperature of column: $40{ }^{\circ} \mathrm{C}$, velocity of flow: $1.0 \mathrm{~mL} / \mathrm{min}$, detector wave- 
length: $280 \mathrm{~nm}$, injection volume: $10 \mu \mathrm{L}$. Methyl cyanide (A) and $2 \%(\mathrm{v} / \mathrm{v})$ acetic acid solution $(\mathrm{pH}=2.59)$ (B) $2 \%$ were used as mobile phases with a gradient elution (B: $100 \%$ (0 min) $\rightarrow 60 \%$ (22.5 min) $\rightarrow 60 \%$ (27 $\mathrm{min}) \rightarrow 37 \%(40.5 \mathrm{~min}) \rightarrow 37 \%$ (42 $\mathrm{min}) \rightarrow 25 \%$ (52 min) $\rightarrow 0 \%$ (55 min) $\rightarrow$ end $(60 \mathrm{~min}))$. Standard phenolic acids used for HPLC analysis were caffeic acid, p-hydroxybenzoic acid, vanillic acid, p-coumaric acid, ferulic acid, benzoic acid and cinnamic acid (Sigma-Aldrich Co. LLC. USA). All chemicals purchased were of high purity and the solvents used were HPLC spectral grade. Major peaks were identified by comparing the retention time with that of the matching standard.

\section{Statistical analyses}

The data were verified for the homogeneity of variance using Levene's test, and an analysis of variance was subsequently performed. The mean separations were performed using Duncan's multiple range tests. Differences at $P=0.05$ were considered to be significant.

\section{Results}

\section{Effects of peanut root exudates on the spore germination of soil-borne pathogens}

The concentration of the added peanut root exudates had significant effect on spore germination. Root exudates from $\mathrm{GH}$ and $\mathrm{QH}$ at the concentrations of $0.1 \mathrm{~g} / \mathrm{L}, 0.5 \mathrm{~g} / \mathrm{L}, 1 \mathrm{~g} / \mathrm{L}$ significantly promoted the spore germination of $F$. oxysporum and $F$. solani as compared to the control (Fig. 1). The concentrations of peanut root exudates from $0.1 \mathrm{~g} / \mathrm{L}$ to $0.5 \mathrm{~g} / \mathrm{L}$ gradually increased the number of germinating spores of Fusarium, however the germination capacity was decreased at the concentration of $1 \mathrm{~g} / \mathrm{L}$ (Fig. 1). Root exudates from $\mathrm{GH}$ at the concentrations of $0.1 \mathrm{~g} / \mathrm{L}, 1$ $\mathrm{g} / \mathrm{L}$ significantly promoted the spore germination of F. oxysporum as compared to that of QH. Root exudates from GH at the concentrations of $0.1 \mathrm{~g} / \mathrm{L}$ significantly promoted the spore germination of $F$. solani as compared to that of $\mathrm{QH}$, and there were no significant differences for other concentrations of root exudates. Briefly, root exudates from GH and QH could significantly stimulate the spore germination of soil-borne pathogens as compared to the control, in which root exudates from $\mathrm{GH}$ had significant greater effect than that of $\mathrm{QH}$.

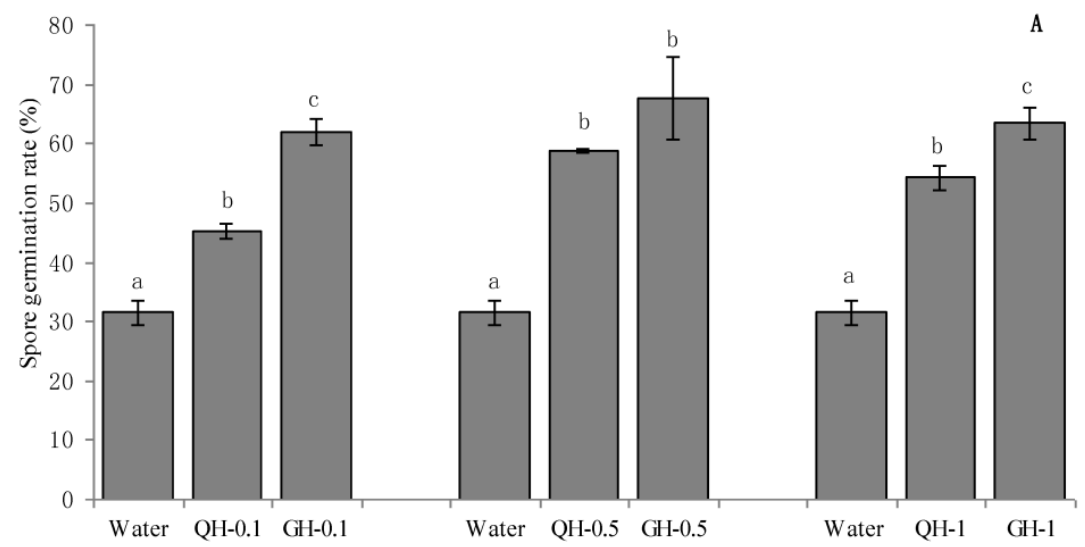

Figure I. Effects of the peanut root exudates at the different concentrations on the spore germination of $F$. oxysporum (A) and $F$. solani (B). The numbers after peanut name in the chart represent the concentrations of peanut root exudates. Different letter superscripts indicate a statistically significant difference $(P<0.05)$ between the control and the treatments with peanut root exudates at the concentrations of $0.1 \mathrm{~g} / \mathrm{L}, 0.5 \mathrm{~g} / \mathrm{L}, \mathrm{I} \mathrm{g} / \mathrm{L}$ respectively.

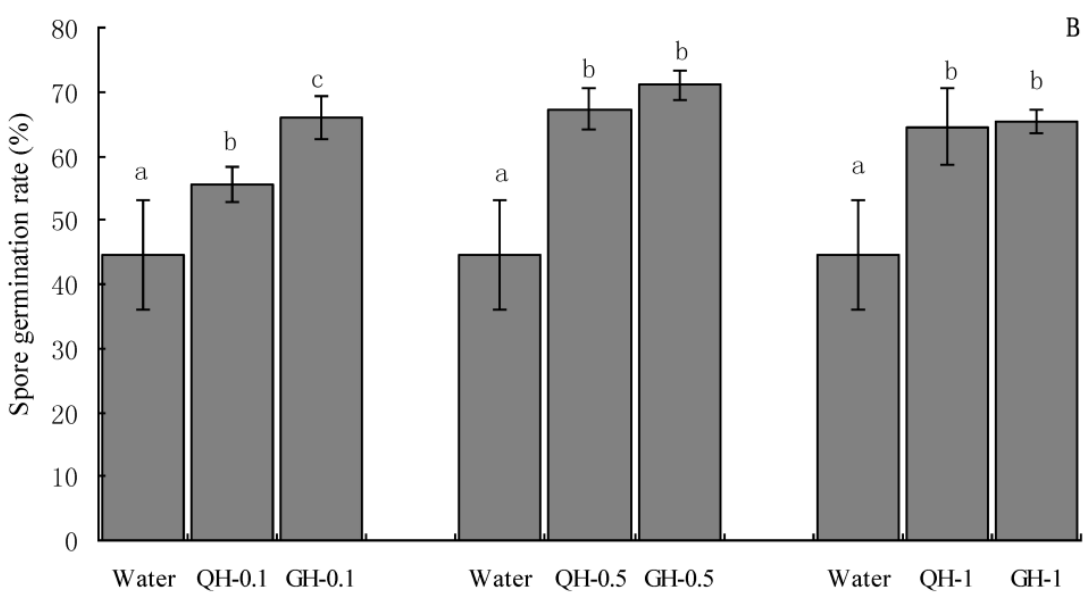




\section{Effects of peanut root exudates on the sporu- lation of soil-borne pathogens}

Root exudates from $\mathrm{GH}$ and $\mathrm{QH}$ at the concentrations of $0.1 \mathrm{~g} / \mathrm{L}, 0.5 \mathrm{~g} / \mathrm{L}, 1 \mathrm{~g} / \mathrm{L}$ significantly promoted the sporulation of F. oxysporum and F. solani as compared to the control. The increase of the concentrations of peanut root exudates from $0.1 \mathrm{~g} / \mathrm{L}$ to $0.5 \mathrm{~g}$ / $L$ gradually increased the number of conidia of $F$. oxysporum and F. solani in liquid culture. In contrast, the number of conidia formed in liquid culture was declined sharply at the concentration of $1 \mathrm{~g} / \mathrm{L}$ (Figs. 2-3). Root exudates from $\mathrm{GH}$ at the concentrations of $0.1 \mathrm{~g} / \mathrm{L}, 0.5 \mathrm{~g} / \mathrm{L}$ significantly promoted the spore germination of F. oxysporum and F. solani as compared to that of QH (Figs. 2-3). In brief, root exudates from $\mathrm{GH}$ and $\mathrm{QH}$ could significantly stimulate the sporulation of soil-borne pathogens as compared to the control, in which root exudates from GH had greater effect than that of $\mathrm{QH}$.

\section{Effects of peanut root exudates on the mycelial growth of soil-borne pathogens}

The colony diameters on water agar containing the root exudates from $\mathrm{GH}$ and $\mathrm{QH}$ were larger than that of the colonies grown on water agar (Fig. 4). The increase of the concentrations of peanut root exudates from $0.1 \mathrm{~g} / \mathrm{L}$ to $0.5 \mathrm{~g} / \mathrm{L}$ gradually increased the colony diameters of Fusarium, although the diameter of the colonies were decreased at the concentration of 1 $\mathrm{g} / \mathrm{L}$. Particularly significant stimulation of the mycelial growth of soil-borne pathogen was obtained when the concentration of the added peanut root exudates was at $0.5 \mathrm{~g} / \mathrm{L}$ (Fig. 4). There were no significant differences between the root exudates of $\mathrm{GH}$ and $\mathrm{QH}$ at three concentrations respectively. In brief, the addition of peanut root exudates could promote the mycelial growth of soil-borne pathogens, but the extent of stimulation was inferior to its effect on the sporulation and spore germination.

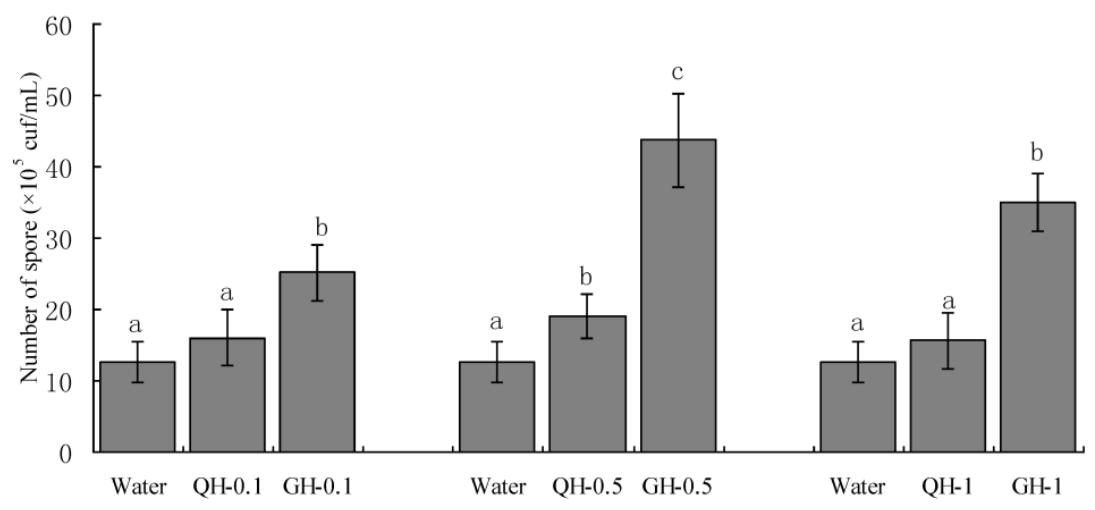

Figure 2. Effects of the root exudates from $\mathrm{GH}$ and $\mathrm{QH}$ at the different concentrations on the sporulation of $F$. oxysporum. The numbers after peanut name in the chart represent the concentrations of peanut root exudates. Different letter superscripts indicate a statistically significant difference $(P<0.05)$ between the control and the treatments with peanut root exudates at the concentrations of $0.1 \mathrm{~g} / \mathrm{L}, 0.5 \mathrm{~g} / \mathrm{L}$, I g/L respectively.

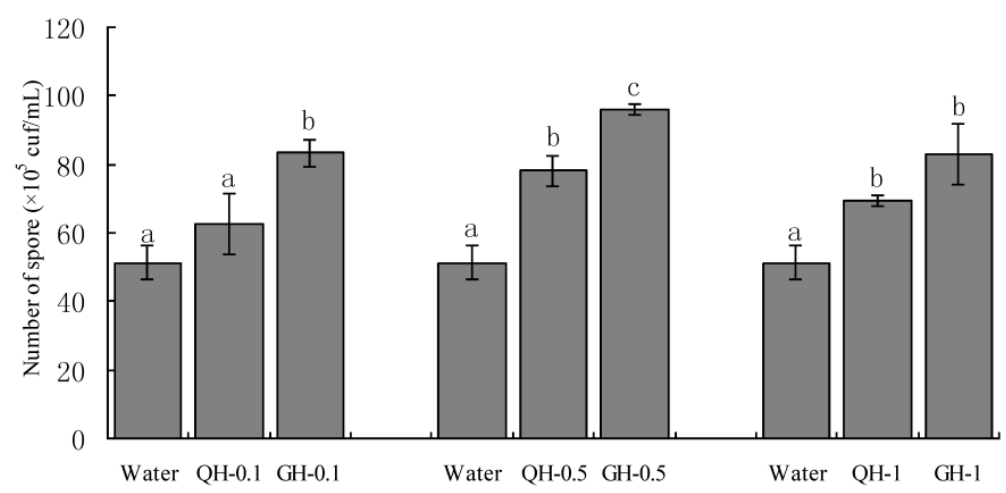

Figure 3. Effects of the root exudates from $\mathrm{GH}$ and $\mathrm{QH}$ at the different concentrations on the sporulation of $F$. solani. The numbers after peanut name in the chart represent the concentrations of peanut root exudates. Different letter superscripts indicate a statistically significant difference $(P<0.05)$ between the control and the treatments with peanut root exudates at the concentrations of $0.1 \mathrm{~g} / \mathrm{L}, 0.5 \mathrm{~g} / \mathrm{L}$, I g/L respectively. 

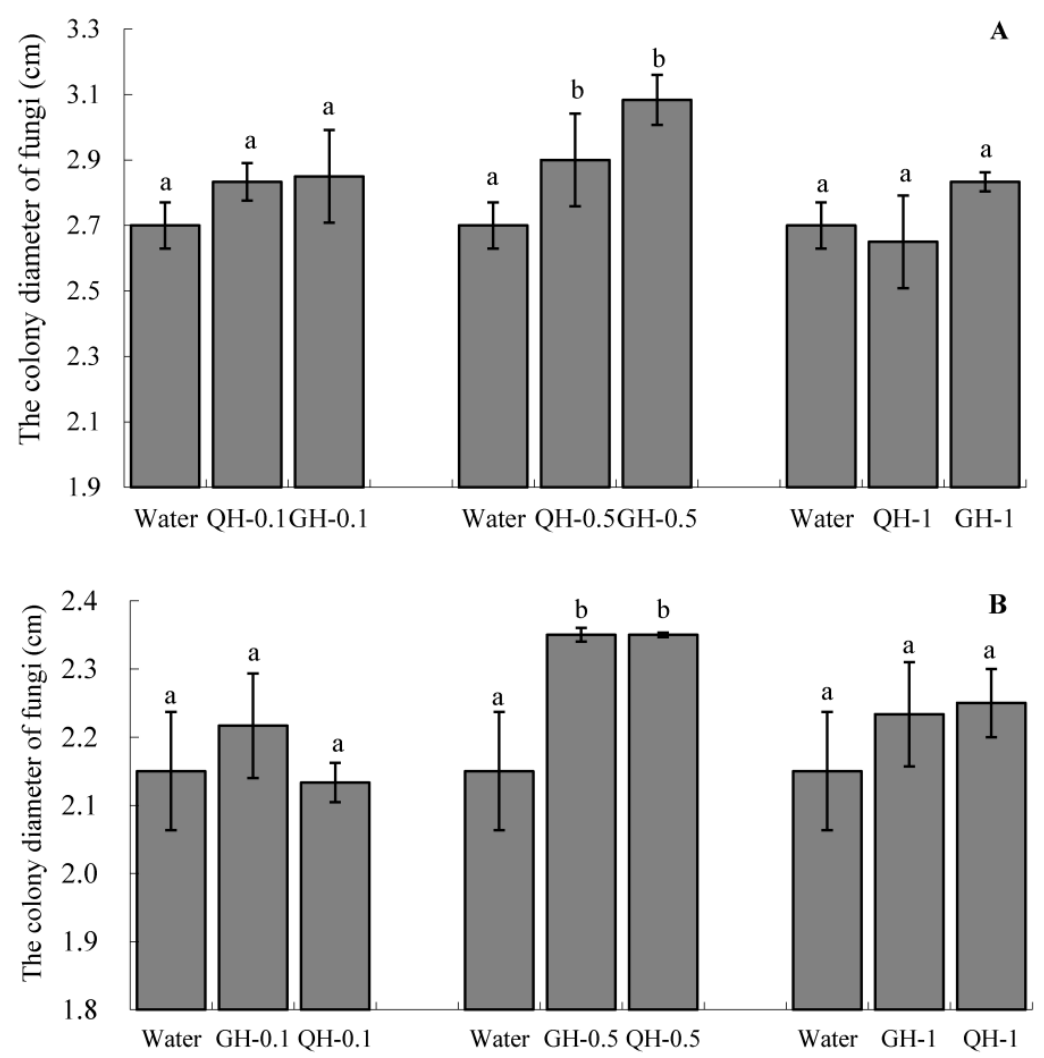

Figure 4. Effects of the peanut root exudates at the different concentrations on the mycelial growth of $F$. oxysporum (A) and $F$. solani (B). The numbers after peanut name in the chart represent the concentrations of peanut root exudates. Different letter superscripts indicate a statistically significant difference $(P<0.05)$ between the control and the treatments with peanut root exudates at the concentrations of $0.1 \mathrm{~g} / \mathrm{L}, 0.5 \mathrm{~g} / \mathrm{L}, \mathrm{I} \mathrm{g} / \mathrm{L}$ respectively.

\section{Determination of soluble sugar and amino ac- ids in peanut root exudates}

Amount of soluble sugars was detected from the peanut root exudates, in which the content in GH was significantly higher than that in QH (Fig. 5). There was no notable difference in the kinds of free amino acids between the root exudates of $\mathrm{GH}$ and $\mathrm{QH}$ (Fig. 6). Ten kinds of free amino acids were detected in the root exudates of two cultivars, including as aspartic acid (Asp), threonine (Thr), glutamic acid (Glu), glycine (Gly), alanine (Ala), valine (Val), lysine (Lys), proline (Pro), histidine (His) and arginine (Arg) (Fig. 6). The most abundant amino acids in the root exudates of $\mathrm{GH}$ and $\mathrm{QH}$ were Arg, Pro and Gly. The contents of Ala and Pro in the root exudates of GH were significantly higher than that in $\mathrm{QH}$, and no significant differences were found in the other amino acids contents (Fig. 6).

\section{Identification and quantification of phenolic acids in peanut root exudates}

The phenolic compounds obtained from the root exudates of $\mathrm{GH}$ and $\mathrm{QH}$ were analyzed using HPLC. According to the retention times of the phenolic acid standards, $p$-hydroxybenzoic acid, coumaric acid and benzoic acid were detected in the root exudates of GH and $\mathrm{QH}$, while cinnamic acid was only found in the root exudates of GH (Table 1). The content of $p$-hydroxybenzoic acid, coumaric acid, benzoic acid and total phenolic acid present in the root exudates of GH were noticeably lower than those found in the root exudates of $\mathrm{QH}$. Moreover, the content of benzoic acid was the highest among the phenolic acids identified in peanut root exudates and accounted for up to $60 \%$ of the total phenolic content.

Table I. Quantitative determination by HPLC of phenolic acids in the root exudates of $\mathrm{GH}$ and $\mathrm{QH}(\mu \mathrm{g} / \mathrm{mL})$

\begin{tabular}{|c|c|c|c|c|c|}
\hline $\begin{array}{l}\text { Peanut } \\
\text { cultivars }\end{array}$ & $\begin{array}{l}\text { p-hydroxybenzoic } \\
\text { acid }\end{array}$ & $\begin{array}{l}\text { coumaric } \\
\text { acid }\end{array}$ & $\begin{array}{l}\text { benzoic } \\
\text { acid }\end{array}$ & $\begin{array}{l}\text { cinnamic } \\
\text { acid }\end{array}$ & $\begin{array}{l}\text { Total } \\
\text { contents }\end{array}$ \\
\hline$\overline{\mathrm{GH}}$ & 0.04 & 0.08 & 0.58 & 0.33 & 1.04 \\
\hline $\mathrm{QH}$ & 0.29 & 0.33 & 0.91 & ND & 1.52 \\
\hline
\end{tabular}

"ND" refers to no detectable. 


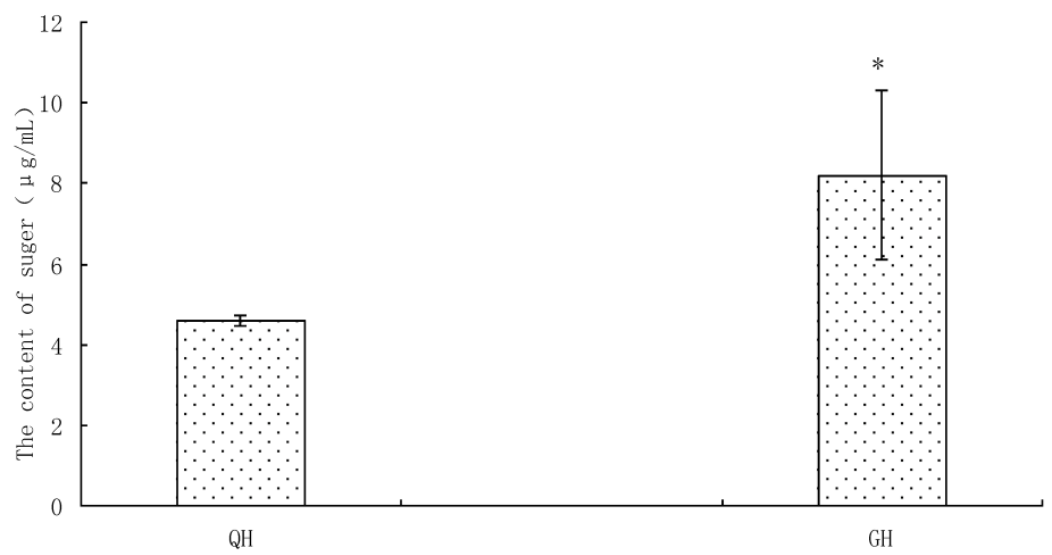

Figure 5. Content of soluble sugar in the root exudates of $\mathrm{GH}$ and $\mathrm{QH}$. * indicates a statistically significant difference $(P<0.05)$ between $\mathrm{GH}$ and $\mathrm{QH}$.

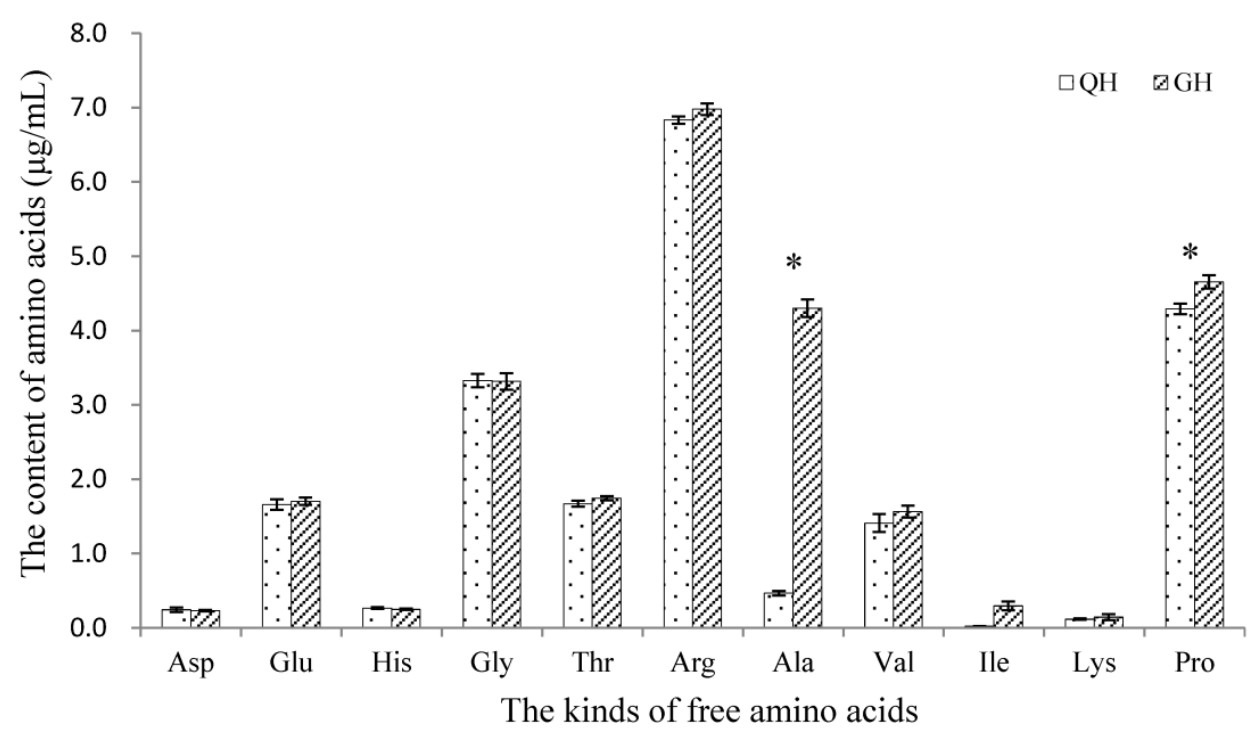

Figure 6. Contents of free amino acids in the root exudates of $\mathrm{GH}$ and $\mathrm{QH}$. * indicates a statistically significant difference $(P<0.05)$ between $\mathrm{GH}$ and $\mathrm{QH}$.

\section{Discussion}

Soil-borne diseases of monoculture peanut field in the red soil regions of southern China seriously affect the yield and quality of peanut. Research findings demonstrated serious incidence of soil-borne diseases, especily peanut root rot and significant decline of yield in the monoculture peanut field [18, 19]. Soil organism can be affected by the exudates secreted from peanut root during its growing period. But how peanut root exadates affect the soil-borne fungi under in vitro condition was not studied before. In the present study, our results showed that peanut root exudates significantly promoted the spore germination, sporulation and mycelial growth of soil-borne pathogens, F. oxysporum and F. solani. These observations could account for our previous results that serious incidence of peanut root rot in the monoculture peanut field [19].

Increasing evidence suggests that root exudates initiate and modulate dialogue between roots and soil microbes, composed of both pathogenic and beneficial microbes [20-24]. For example, plant species (Arabidopsis thaliana and Medicago truncatula) are able to regulate soil fungal community composition through their root exudates [25], and transgenic tobacco that over-accumulates iron selected fluorescent pseudomonads more antagonistic to the plant pathogen than the wild type [26]. These findings showed the importance of root exudates to defend the plants against soil pathogenic microorganisms. It is therefore a good idea to exploit the allelopathic effect of root exudates 
on soil-borne pathogens in peanut moncropping system. Monoculture of French bean resulted in serious incidence of soil-borne diseases, especially Rhizoctonia root rot (Rhizoctonia solani) [27]. Monoculture of soybean increased the numbers of soybean cyst nematodes and soybean fungal pathogens, and caused an obvious allelopathic effect $[28,29]$. The result of this study showed increased stimulation of soil-borne pathogens with the increased concentrations of added peanut root exudates, and thus provided strong theoretical evidence that higher incidence of peanut diseases in the monocropping system of south China might be due to the peanut root exudates.

The relationship between the root exudates and the plant's resistance to soil-borne pathogens, such as F. oxysporum is connected with the components of the root exudates [30,31]. Plant roots release a wide range of compounds including sugars, polysaccharides and amino acids, that are involved in attracting strongly and selectively many bacterial or fungal pathogens and forming the special associations in the rhizosphere $[32,33]$. The kinds and amounts of amino acids and soluble sugars in the root exudates from susceptible cultivars of either cucumber or cotton were much higher than those in resistant ones [9, 10, 12, 13]. Our earlier result also indicated that the amounts of amino acids and soluble sugar were positively and significantly correlated with the disease indices and could be used as important biochemical criteria for predicting plant resistance to soil-borne diseases [14]. GH is a susceptible cultivar with the poor resistance to soil-borne diseases, such root rot and bacterial wilt, while $\mathrm{QH}$ is a resistant cultivar with the good resistance. The result of our study showed the content of sugar and amino acids in the root exudates of $\mathrm{GH}$ were higher than that in $\mathrm{QH}$, and the root exudates of $\mathrm{GH}$ had greater stimulative effects on soil-borne pathogens than that of $\mathrm{QH}$, which were probably one of main reasons for the different resistance of this two cultivars to soil-borne diseases.

Some phenolic acids, such as hydroxybenzoic acid, vanillic acid, coumaric acid and benzoic acid were detected in soils from the monoculture peanut fields by HPLC, and increased with the prolonged planting-year of peanut [19]. In the present study, hydroxybenzoic acid, coumaric acid and benzoic acid were also identified in the root exudates of both peanut cultivars upon HPLC analysis that were consistent to the result of Li et al. (2010). The amount of coumaric acid, benzoic acid and total phenolic acids in the root exudates of $\mathrm{GH}$ was much lower than that from QH. Furthermore, cinnamic acid was only found in the root exudates of GH (Table 1). Several interrelationships between conidial germination and cin- namic acid concentration may exist. For example, the high concentration of cinnamic acid not only significantly promoted the conidial germination of $F$. oxysporum, but also significantly increased the incidence of Fusarium wilt in cucumber plants [34-36]. Overall, the presence and absence of these specific phenolic acids and their different effects on soil-borne pathogens may explain the different resistance of the tested peanut cultivars to soil-borne pathogens.

Root exudates from disease-resistant varieties are known to supply fewer nutrients to F. oxysporum [37], or to contain inhibitory substances to pathogens [38]. The contents of sugars and amino acids e.g. Ala, Asp and Glu in the root exudates of disease-susceptible varieties were more abundant than in disease-resistant varieties [9, 10, 14]. Booth (1969) compared the amino acid contents of the root exudates of cotton varieties that were either resistant or susceptible to Verticillium wilt [39]. Among the eight amino acids tested in his study, the greatest difference in the amino acid content was Ala, and no major differences were determined in the contents of the other seven amino acids. Ala could obviously promote the spore germination of soil-borne pathogens in vitro [7, 10]. Our results showed large number of sugars and amino acids secreted by peanut roots. Moreover, the contents of sugars and amino acids in the root exudates of $\mathrm{GH}$ were higher than in $\mathrm{QH}$, and very significantly differences were observed in Ala content. These results were consistent with the aforementioned studies, indicating that the root exudates of peanut could provide abundant nutrition for the growth, development and host invasion of soil-borne pathogen, such as F. oxysporum and F. solani. This is probably one of the reasons for the observed increased incidences of peanut root rot in monocultuer system.

The study determined that the stimulation of soil-borne pathogens was decreased when the concentration of peanut root exudates was added to $1 \mathrm{~g} / \mathrm{L}$ under in vitro condition, which suggested that the peanut root exudates contained some amount of botanical antimicrobial substances. Some studies found that phenol acids, especially benzoic acid and its derivatives in the plant root exudates can act as growth inhibitors to the soil organism or plant itself $[7,19,40$, 41]. For example, Ju et al. (2002) reported that the high-concentration phthalic acid and malonic acid (1 $\mathrm{g} / \mathrm{L})$ have allelopathic inhibitory effects on the growth of pathogenic fungi of soybean root rot [42]. Hao et al. (2010) and Zhou and $\mathrm{Wu}$ (2012) also found that $p$-coumaric acid more than $70 \mu \mathrm{g} / \mathrm{mL}$ can have the significant inhibition to F. oxysporum [7, 43]. In the present study, the concentrations of some phenol ac- 
ids, including $p$-hydroxybenzoic acid, coumaric acid and benzoic acid determined in the peanut root exudates were lower than $1 \mu \mathrm{g} / \mathrm{mL}$. The results above strongly suggested that these phenol acids may be not the only antimicrobial substances, and peanut root exudates could contain other substances. More recently, several papers have documented that organic acids, esters, diterpenes and cyclohexenone are potent allelochemicals in the root exudates [44-47]. These chemicals also exhibit promising suppression of fungal pathogens. Whether these compounds also exist in peanut root exudates and what effect they could have on the growth of soil-borne pathogens remains unknown. Therefore, further clarification and identification of these allelochemicals is warranted.

The method for root exudates collection we used, by immersion of root systems into an aqueous media for a defined time period, is easy to perform and reflects the changes of secretion of the whole roots. However, this method also has its restrictions, such as the mechanical impedance imposed on roots is weaker in liquid culture media resulting in lower concentrations of root exudates than in the solid growth media [7]. Therefore, a better method for root exudates collection should be developed to disclose the natural secretion of plant.

The findings of the study demonstrated that peanut root exudates significantly promoted the growth of soil-borne pathogens, and its stimulation was increased with the increased concentrations of added peanut root exudates under in vitro condition. Peanut root exudates contained sugars, amino acids and phenol acids, and had greatly different compositions between the different cultivars, which suggested that the kinds and content of root exudates could be used as important biochemical criteria for predicting peanut resistance to soil-borne diseases. It is proposed that peanut root exudates were possibly one of the key reasons for the observed higher incidence of peanut diseases in monocultuer system.

Obviously, root exudates play vital role in the peanut replanted obstacle, especially the interaction of soil-borne pathogens. However, it needs to conduct comprehensive studies on this issue as root exudates are complex in types and vary greatly in composition, and only a part of allelochemicals have been analysed, many of them have biological activities and always cause the cumulative effects. Therefore, comprehensive effect of root exudates needs to be determined to get a full disclosure of their effect on soil-borne pathogens in monoculture peanut field. In addition, soil-borne pathogens are only a little portion of soil microorganisms, the high incidence of soil-borne diseases was often caused comprehensively by the change of soil organisms in monoculture peanut field. Therefore, further investigations are expected to find out the influence of peanut root exudates on soil bacterial community structure, fungal community structure and antagonistic bacteria such as Pseudomonas, Actinomycetes etc.

\section{Acknowledgements}

This research was jointly supported by the National Natural Science Foundation of China (41201281), the Knowledge Innovation Program of Chinese Academy of Sciences (ISSASIP1107), and the GanPo 555 Talents Program of Jiangxi Province. We thank Dr. Mohammad-Saiful Alam at the State Key Laboratory of Soil and Sustainable Agriculture, Institute of Soil Science, China for polishing English of this manuscript, and we are also very grateful to Pro. Liu Biao from Nanjing Institute of Environmental Sciences, Ministry of Environmental Protection of China, for providing a strain of $F$. oxysporum used in the study.

\section{Competing Interests}

The authors have declared that no competing interest exists.

\section{References}

1. Wang MZ, Chen XN. Obstacle and countermeasure of sustainable high yield for peanut in low-hilly red soil region. J Peanut Sci. 2005; 34: 17-22.

2. Chen ZC, Zou XF, Song LQ, Zuo XY. Obstacle and countermeasure of sustainable high yield for peanut in Jiangxi province. Acta Agri Jiangxi. 2008; 20: 165-166.

3. Gil VS, Haro R, Oddino C, Kearney M, Zuza M, Marinelli A, March GJ. Crop management practices in the control of peanut diseases caused by soilborne fungi. Crop Prot. 2008; 27: 1-9.

4. Bertin C, Yang X, Weston L. The role of root exudates and allelochemicals in the rhizosphere. Plant Soil. 2003; 256: 67-83.

5. Dixon RA. Natural products and plant disease resistance. Nature. 2001; 411: 843-847.

6. D'Auria JC, Gershenzon J. The secondary metabolism of Arabidopsis thaliana: growing like a weed. Curr Opin Plant Biol. 2005; 8: 308.

7. Hao WY, Ren LX, Ran W, Shen QR. Allelopathic effects of root exudates from watermelon and rice plants on Fusarium oxysporum f.sp. niveum. Plant Soil. 2010; 336: 485-497.

8. Buton EW. Root exudates from banana and their relationship to strains of the Fusarium causing Panama wilt. Ann Appl Biol. 1962; 50: 269-282.

9. Yuan HX, Li HL, Wang Y, Fang WP, Wang ZY. The root exudates of cotton cultivars with the different resistance and their effects on Verticillium dahliae. Acta Phytopathol Sin. 2002; 2: 127-131.

10. Wu YX, Shen XJ, Fang WP. The effects of cotton root exudates on growth and development of Verticillium dahliae. Cotton Sci. 2007; 19: 286-290.

11. Jones DL, Hodge A, Kuzyakov Y. Plant and mycorrhizal regulation of rhizodeposition. New Phytol. 2004; 163: 459-480.

12. Han X, Pan K, Wu FZ. Effect of root exudates from cucumber cultivars on the growth of Fusarium oxysporum. China Veg. 2006; 5: 13-15.

13. Wu FZ, Meng LJ, Wen JZ. Effects of root exudates of cucumber on mycelium growth of Fusarium wilt. China Veg. 2002; 5: 26-27.

14. Li XG, Liu B, Sondre H, Liu DD, Han ZM, Zhou KX, Cui JJ, Luo JY, Zheng YP. The effect of root exudates from two transgenic insect-resistant cotton lines on the growth of Fusarium oxysporum. Transgenic Res. 2009; 18: 757-767

15. Sun TF. NO.5 Ganhua- new cultivar of peanut. Chin J Oil Crop Sci. 1995; 2: 63 .

16. Cheng JH, Chen YS, Chen SL, Luo WL, Chen RY, Zhuang MC. Breeding of a new peanut variety Quanhua7. J Peanut Sci. 2008; 37: 41-44.

17. Booth C. The genus Fusarium. Common wealth Mycological Institute, Kew, Surrey, England. 1971; : 32-35. 
18. Dai CC, Xie H, Wang XX, Li PD, Zhang TL, Li YL, Tan X. Intercropping peanut with traditional Chinese medicinal plants improves soil microcosm environment and peanut production in subtropical China. Afr J Biotechnol. 2010; 8: 3739-3746.

19. Li PD, Wang XX, Li YL, Wang HW, Liang FY, Dai CC. The contents of phenolic acids in continuous cropping peanut and their allelopathy. Acta Ecol Sin. 2010; 30: 2128-2134.

20. Bais HP, Prithiviraj B, Jha AK, Ausubel FM, Vivanco JM. Mediation of pathogen resistance by exudation of antimicrobials from roots. Nature. 2005; 434: 217-221.

21. Bais HP, Weir TL, Perry LG, Gilroy S, Vivanco JM. The role of root exudates in rhizosphere interactions with plants and other organisms. Annu Rev Plant Biol. 2006; 57: 233-266.

22. Garbeva P, Van Veen JA, Van Elsas JD. Microbial diversity in soil: selection of microbial populations by plant and soil type and implications for disease suppressiveness. Annu Rev Phytopathol. 2004; 42: 243-270.

23. Houlden A, Timms-Wilson TM, Day MJ, Bailey MJ. Influence of plant developmental stage on microbial community structure and activity in the rhizosphere of three field crops. FEMS Microbiol Ecol. 2008; 65:193-201.

24. Rudrappa T, Kirk J, Czymmek PW, Paré PW, Bais HP. Root-secreted malic acid recruits beneficial soil bacteria. Plant Physiol. 2008; 148: 1547-1556.

25. Broeckling CD, Broz AK, Bergelson J, Manter DK, Vivanco JM. Root exudates regulate soil fungal community composition and diversity. Appl Environ Microbiol. 2008; 74: 738-744.

26. Robin A, Mazurier S, Mougel C, Vansuyt G, Corberand T, Meyer JM, Lemanceau P. Diversity of root-associated fluorescent pseudomonads as affected by ferritin overexpression in tobacco. Environ Microbio. 2007; 9:1724-1737.

27. Joshi D, Hooda KS, Bhatt JC, Mina BL, Gupta HS. The rhizosphere: a playground and battlefield for soilborne pathogens and beneficial microorganisms. Plant Soil. 2009; 321: 341-361.

28. Chen LJ, Zhu Y, Liu B, Duan YX. Influence of continuous cropping and rotation on soybean cyst nematode and soil nematode community structure. Acta Phytophylacica Sinica. 2007; 34: 347-352.

29. Han LM, Qu HY, Wang XM. Influence of the organic compounds in cropping soybean on pathogenic of root rot. Soybean Sci. 2004; 23: 36-40.

30. Steinkellner S, Mammerler R, Vierheilig H. Microconidia germination of the tomato pathogen Fusarium oxysporum in the presence of root exudates. J Plant Interact. 2005; 1: 23-30.

31. Bais HP, Weir TL, Perry LG, Gilroy S, Vivanco JM. The role of root exudates in rhizosphere interactions with plants and other organisms. Annu Rev Plant Biol. 2006; 57: 233-266.

32. Brencic A, Winans SC. Detection of and response to signals involved in host-microbe interactions by plant-associated bacteria. Microbiol Mol Biol Rev. 2005; 69: 155-194.

33. Yao J, Allen C. Chemotaxis is required for virulence and competitive fitness of the bacterial wilt pathogen Ralstonia solanacearum. J Bacteriol. 2006; 188: 3697-3708.

34. Ye SF, Yu JQ, Peng YH, Zheng JH, Zou LY. Incidence of Fusarium wilt in Cucumis sativus L. is promoted by cinnamic acid, an autotoxin in root exudates. Plant Soil. 2004; 263:143-150.

35. Ye SF, Zhou YH, Sun Y, Zou LY, Yu JQ. Cinnamic acid causes oxidative stress in cucumber roots, and promotes incidence of Fusarium wilt. Environ Exp Bot. 2006; 56:255-262.

36. Ling N, Huang QW, Guo SW, Shen QR. Paenibacillus polymyxa SQR-21 systemically affects root exudates of watermelon to decrease the conidial germination of Fusarium oxysporum f.sp. niveum. Plant Soil. 2011; 341:485-493.

37. Steinkellner S, Mammerler R, Vierheilig H. Germination of Fusarium oxysporum in root exudates from tomato plants challenged with different Fusarium oxysporum. Eur J Plant Pathol. 2008; 122: 395-401.

38. Nóbrega FM, Santos IS, Cunha MD, Carvalho AO, Gomes VM. Antimicrobial proteins from cowpea root exudates: inhibitory activity against Fusarium oxysporum and purification of a chitinase-like protein. Plant Soil. 2005; 272: 223-232.

39. Booth JA. Gossypaum harsutum tolerance to Verticillium dahliae infection I. Amino acids exudation from aseptic roots of tolerant and susceptible cotton. Phytopathology. 1969; 59: 43-46.

40. Rimando AM, Olofsdotter M, Dayan FE, Duke SO. Searching for rice allelochemicals: an example of bioassay-guided isolation. Agron J. 2001; 93: 16-20.

41. Wu CW, Du XF, Xu JM, Wang WZ. Research advances in natural antibacterial constituents from plant origin. Acta Agri Boreali-occidentalis Sinica. 2004; 13: 81-88.
42. Ju HY, Han LM. Influence of root exudations on pathogenic fungi produced by root rot and seed germination in continuous cropping soybean. J Jilin Agri Univers. 2002; 24: 45-49.

43. Zhou X, Wu F. p-Coumaric acid influenced cucumber rhizosphere soil microbial communities and the frowth of Fusarium oxysporum f.sp. $\mathrm{cu}$ cumerinum Owen. PLoS ONE. 2012; 7(10): e48288.

44. Kong CH, Xu XH, Hu F, Chen XH, Ling B, Tan ZW. Using specific secondary metabolites as markers to evaluate allelopathic potentials of rice varieties and individual plants. Chin Sci Bull. 2002; 47:839-843.

45. Kong $\mathrm{CH}, \mathrm{Xu} \mathrm{XH}$, Zhou $\mathrm{B}, \mathrm{Hu} \mathrm{F}$, Zhang $\mathrm{CX}$, Zhang MX. Two compounds from allelopathic rice accession and their inhibitory activity on weeds and fungal pathogens. Phytochemistry. 2004; 65:1123-1128.

46. Kato-Noguchia $H$, Ino $T$, Kujime $H$. The relation between growth inhibition and secretion level of momilactone B from rice root. J Plant Interact. 2010; 5:87-90.

47. Li XG, Wei Q, Liu B, Alam MS, Wang XX, Shen WJ, Han ZM. Root exudates of transgenic cotton and their effects on Fusarium oxysporum. Front Biosci-Landmark. 2013; 18: 725-733. 